\title{
Water Springs Research in Utena District (Lithuania)
}

\author{
Ingrida Kepalaitė \\ Utena University of Applied Sciences, Faculty of Business and Technologies
}

\begin{abstract}
. water springs can be researched like the objects of geo heritage, geo diversity, geo tops, nature, drinking water resources, mythology, tourism objects and others. They are important from the scientific, aesthetic, tourism, and cultural points of view. This article aims to analyse water springs as geo tops, geo heritage and drinking water resources. The content of water's chemical structure, cations and anions in spring water will be taken into account. After the water quality analysis in Utena district was made, it was set that the prevailing springs' water is slightly alkaline hard water of relatively low conductivity. The prevailing anions are hydrocarbonates, and the prevailing cations - calcium, sodium, magnesium. The amount of the nitrates does not exceed the limits.
\end{abstract}

Keywords: Geo heritage, Geo diversity, Geo top, Geo sites, pH, cations and anions.

\section{INTRODUCTION}

We rarely talk about the destruction of geological and geomorphologic objects because of the same reasons, especially because of agricultural development, construction. The mechanic erosion destroys the hills, deteriorates the soil. It is important to determine the priorities of research and protection. More than twenty years ago, scientists have made a distinction only one category - the geographical extremes. There are the largest, longest, deepest natural objects. Now scientists distinguish much more categories. For example geo diversity, geo hertage, geo sities, geo tops and other. [1] These categories are interrelated. The geo tops were started to analyze latest. Mostly analyzed geo tops in Lithuania are water springs. In this article the main attention will be paid to the water quality analysis from the springs in Utena district.

\section{MATERIALS AND METHODS}

Firstly, we need to determine what the geo diversity is, what most important objects should be included into the geo tops and geo heritage lists and to determine the level of their protection.

Geo heritage defined in the recommendations of Council of Europe (2004) - it is scientific, cultural, aesthetic, landscape, economic and generic value of natural geological objects that must be preserved to the future generations. Present experience shows that geo heritage can be used for recreation, educational tourism, education and training but the most important its value is scientific. [1]

Geo diversity can be described as the variety of elements of geology — the rocks, minerals, fossils and soils - and the natural landforms and processes that shape them throughout geological time. Geo diversity also recognises the link between people, landscape and their culture. The recognition of the concept of geo diversity represents an opportunity for the geological sciences to raise their profile, and raise awareness of the importance of abiotic parts of ecosystems. Geo diversity is the process of recognising and assessing the value of geological features, collections, sites, monuments, artworks, and landscapes and the application of practices for their care, maintenance and management for the long-term benefit of all. [2]

Beside the state protected geo heritage objects, there is one more geo heritage category - geo tops. They are scientifically and educationally (unique and reference) important geological, geomorphologic, hydrogeological objects and their groups - forms of relief, outcrop, boulders and their accumulations, high yield or increased mineralization ground water springheads, excavations, exposures and others. Very often they have huge aesthetic, tourist, archaeological, historical and cultural value. Most of them already have the status of nature heritage objects, the others are potentially claimed to be protected by the state. Part of the geo tops are in the private property or formed by human. [3]

Since 1995 - geo tops are analysed and registered by Lithuania Geology Service by the Ministry of Environment. They are registered in the Geo tops subsystem of the State geology informative system. In this subsystem it is possible now to find information about 641 geological, geomorphologic, hydro geological and hydrographical natural heritage objects. Geo tops are determined by carrying out state geological mapping, special scientific research, getting information from 
research organisations, individual nature explorers and promoters, and the directions of protected territories. [4]

Every state (municipality) has to „collect“ (register) its explored geo collection made up from geo diversity, geo heritage, geo tops and other reference and unique natural objects. This list will enable to know the available objects, research, protect them and be proud of them. [1]

The mostly researched geo tops in Lithuania are water springs. Springhead or water spring is the place where underground water exudes from the underground naturally. The concentrated spontaneous underground water outfall to the ground surface or under the water happens. It often forms there where the underground water layers are being crossed by the present relief forms (valleys, ravines, lake pits). It can also form due to geological-structural features of the locality, the rock filtration. Most authors of the world classify the sources according to the overflow conditions on the ground surface, duration of action, abundance of water, chemical structure and temperature. The water springs could be rising, falling, permanent, seasonal and temporary, freshwater and mineral and others. According to the origin of the feeding water, the springs can be divided into surface, ground or artesian. [5]

The springs, rising from the compressible watery layers, are characterized as having quite stable chemical structure, yield, temperature, and the quality of the ground water springs often depend on pollution objects or the agricultural or any other activities performed in the surroundings (nutrition area), the yield and the temperature can change in the bigger range. [5]

The quality of the water in the local groundwater system will generally determine the quality of spring water. The quality of water discharged by springs can vary greatly because of factors such as the quality of the water that recharges the aquifer and the type of rocks with which the groundwater is in contact. The rate of flow and the length of the flowpath through the aquifer affects the amount of time the water is in contact with the rock, and thus, the amount of minerals that the water can dissolve. [7]

The water springs are not used for water supply or irrigation in Lithuania. In most cases the water springs" water is used by the people living nearby. In order to find out if the spring is suitable for the water supply, firstly the watery layer that feeds the spring must be identified. If the spring is fed by the subsoil waters, it is not suitable for the water supply because it has low abundance of water, it can be easily contaminated or to dry up in certain season. The springs fed by the ground waters are worth our attention.
Lithuanian hydrogeologists estimated that it is possible to get over 3 million $\mathrm{m}^{3}$ fresh drinking water from the underground without making any damage to environment. [5]

Groundwater zone of bicarbonates is spread on the entire country and is used for drinking water supply. Thickness of it is changing from $200-400 \mathrm{~m}$ at Baltija and Žemaičiai highland, to $50-150 \mathrm{~m}$ at the Nemunas lowland. Despite differences of chemical composition and mineralization in various aquifers or parts of them, the ions of bicarbonate and calcium prevails. A groundwater of sulfate, chloride-sulfate and chloride hydrochemical zones is used or could be used in future for balneologic and industrial purposes. (Both can be active in future). [6]

\section{RESULTS AND DISCUSSION}

Lately, a lot of water springs are being researched in the protected territories of Lithuania's by Lithuania Geology Service by the Ministry of Environment. So that there would be as less unsearched water springs in other places, the decision to research a few water springs in Utena district was made.

The quality of the water was analysed from 9 water springs in Utena district. The position of the water springs is shown on the map made by Arcgis online programme (Figure 1). There are two springs in one place, called Lydekos in Figure 1 (Didžioji lydeka and Mažoji lydeka).

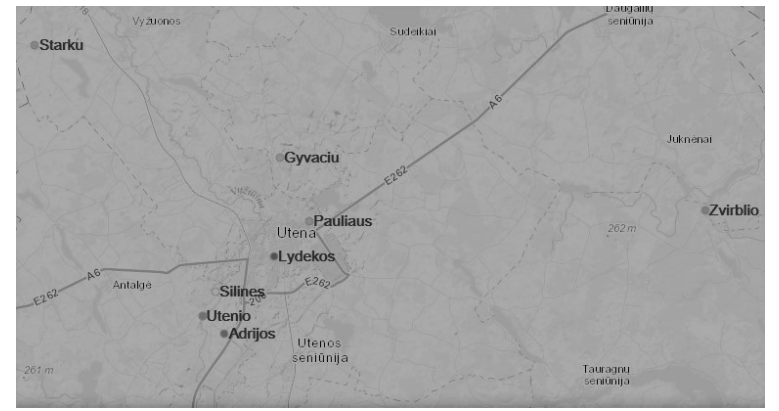

Fig. 1. The position of the water springs analysed in Utena district

The water analysis was carried out in a certified laboratory by Lithuania Geology Service by the Ministry of Environment. The laboratory, while analysing the water, follow the hygiene norm HN 24:2003 of the Republic of Lithuania "Safety and quality requirements for drinking water". Various water quality indicators were analysed.

Acids and alkalis balance indicator $\mathrm{pH}$ (hydrogen ions concentration indicator) influences physical features of water. It varies from the most acid - 0 to the most alkaline -14 . The environment, where $\mathrm{pH}$ is equal to 7 , is called neutral. While analysing the water springs in Utena district, the hydrogen ions concentration indicator in the water was set Figure 2). In different springs in Utena district $\mathrm{pH}$ varies not so much, it is from 7,63 to 8,47 because slightly alkaline water prevails in Lithuania. This chemical water indicator is not regulated in the hygiene norm HN 24:2003 because drinking water is close to 
neutral value and does not have influence to people's health.

Under natural conditions the water is not chemically pure $\left(\mathrm{H}_{2} \mathrm{O}\right)$. The underground water is a multicomponent mineral salts solution in which prevail calcium, magnesium, sodium, potassium cations; chloride sulphate hydro carbonate anions and necessary elements (biologically active microelements), which include in various compounds: fluorine, manganese, iron, iodine, zinc, copper and others. Their concentrations and proportions in the water depend on the variety of the hydrogeological conditions, the initial composition of the rocks, where the water lies. The entirety of the inanimate materials dissolved in the water determines the general natural water mineralization and its chemical composition. [5] They influence the taste and smell of the water.

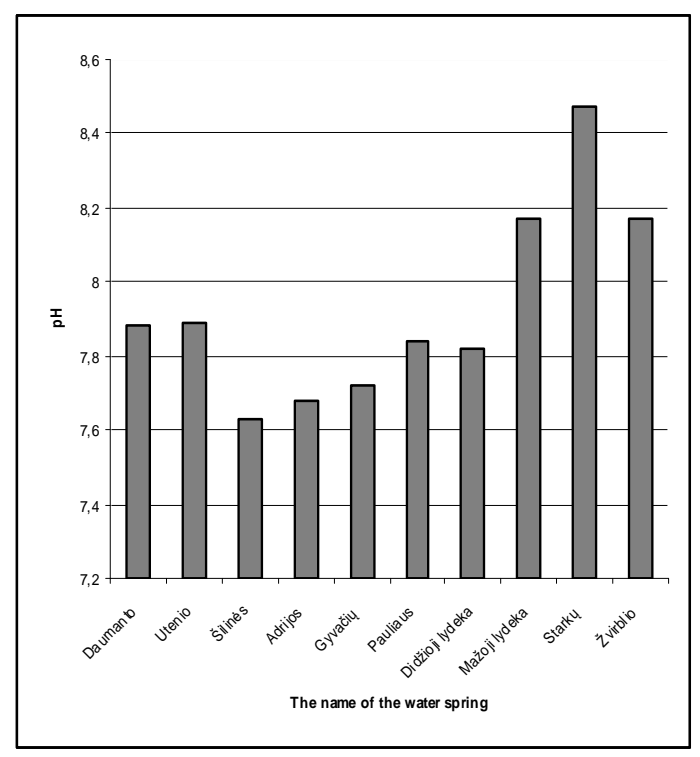

Fig. 2. Hydrogen ion concentration, $\mathrm{pH}$ units $20^{\circ} \mathrm{C}$

Distinctive electric conductivity is the physics indicator of water quality. Chemically pure water do not conduct eletricity. Conductivity is provided by the salts ions that are melted in water. HN 24:2003 regulate that distictive electric conductivity would not be over $2500 \mu \mathrm{S} \mathrm{cm}^{-1}$ in $20^{\circ}$ temperature.

In the spring water from Utena district (Figure 3 ) the distinctive electric conductivity is relatively low - from $520 \mu \mathrm{S} / \mathrm{cm}$ (in Utenis spring) to 1081 $\mu \mathrm{S} / \mathrm{cm}$ (in Starkai spring). It means low level of dissolved salt ions.

Hardness in water is determined by entirety of salts in it (calcium and magnesium hydrocarbonates, carbonates, sulphates, chlorides). The salts of water hardness are not harmless to person's health, so it is not regulated.

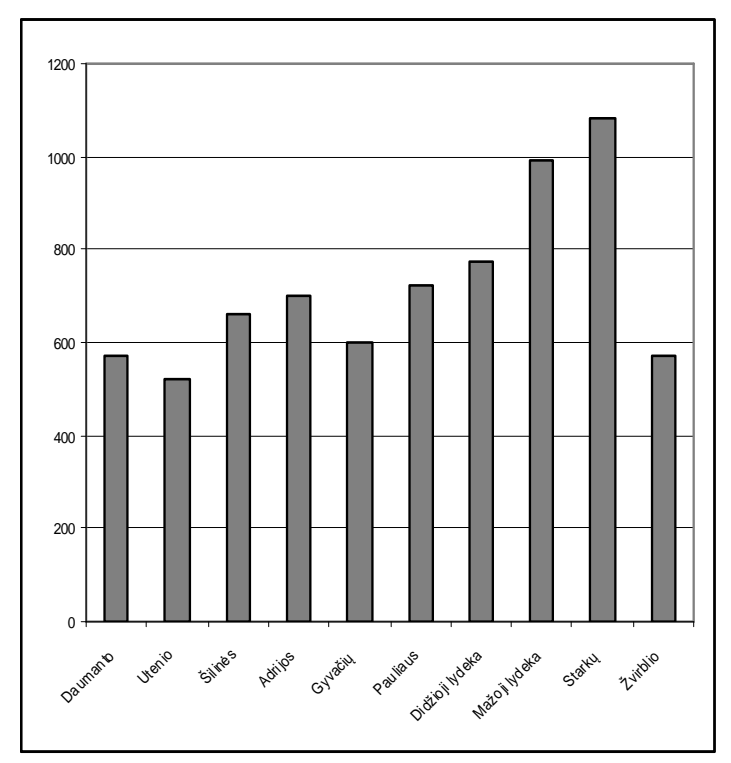

Fig. 3. Distinctive electric conductivity, $\mu \mathrm{S} / \mathrm{cm}$

The water hardness in the springs of Utena district is shown in the Figure 4. Carbonate and non-carbonate hardness make up the general hardness of the water. It is not low, the lowest is in Utenis spring - 5,83 mg-ekv/l, and the highest was set in Starkai spring - 11,93 mg$\mathrm{ekv} / \mathrm{l}$.

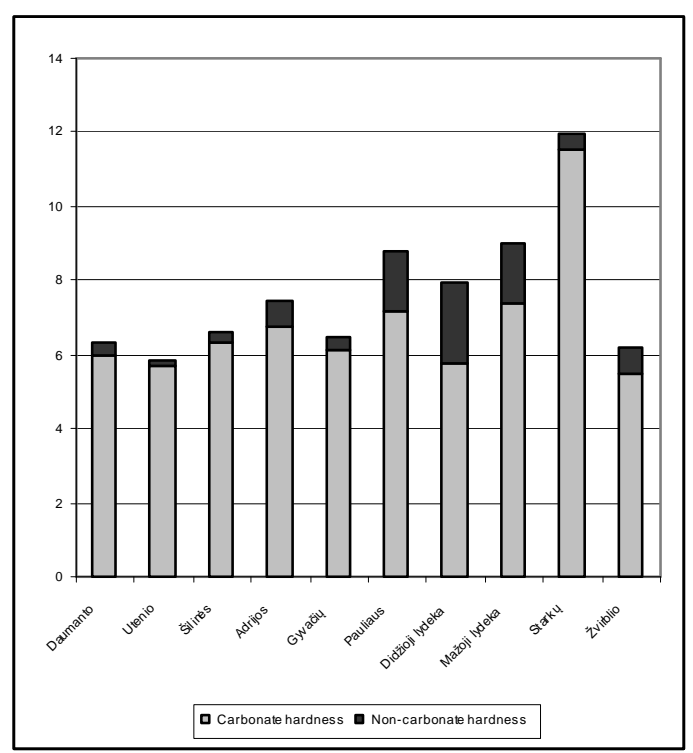

Fig 4. General spring water hardness, mg-ekv/l

The advantage of the carbonate hardness is that it becomes lower when the water is being boiled as it turns into sediment. The highest non-carbonate hardness was set in the springs located in the city.

Sometimes the chemical water's composition is expressed by fake fraction where the meanings of the anions over $10 \% \mathrm{ekv}$. in the descending order are written in the numerator, and the meanings of the cations are written in the denominator (over 10\% ekv.). [5] 


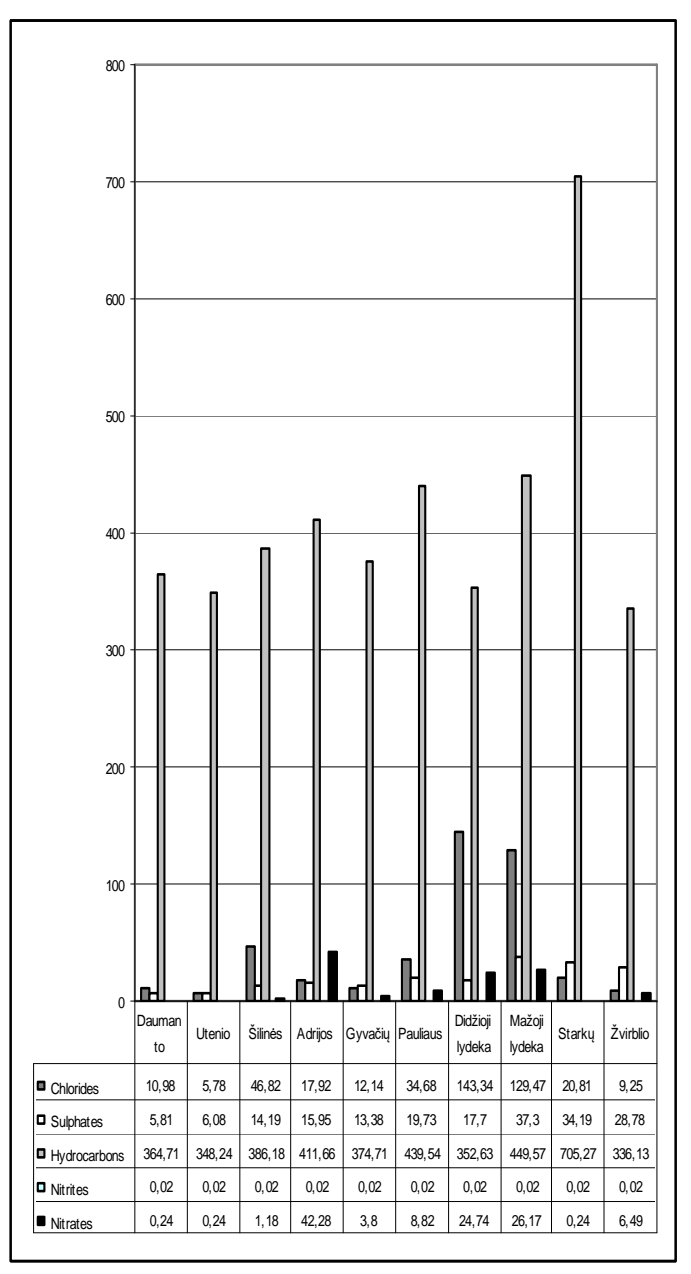

Fig. 5. The amount of anions, $\mathrm{mg} / \mathrm{l}$

So, while performing water quality analysis, the amount of anions and cations is set. In Lithuania hydro carbonate water prevails, and the is obviously proven the analysis of the water from Utena district springs (Figures 5 and 6), where the amount of hydrocarbonates is from $336,13 \mathrm{mg} / \mathrm{l}$ (in Zvirblis spring) to $705,27 \mathrm{mg} / \mathrm{l}$ (in Starkai spring). HN 24:2003 regulates that the amounts of chlorides and sulphates in the water would not exceed $250 \mathrm{mg} / \mathrm{l}$, and these indicators do not come close to limits (Figure 5).

HN 24:2003 regulates the limit value of nitrates $-50 \mathrm{mg} / \mathrm{l}$. The concentration of nitrate sis very different in Utena district springs. It is influenced by the agricultural activities in the surroundings and the pollution of the drinking water. In two springs (The Great and The small pike) located in Utena centre the amount of the nitrates is close to $25 \mathrm{mg} / \mathrm{l}$, and in one spring (Adrija) it is $42,28 \mathrm{mg} / \mathrm{l}$. In other springs the amount of nitrates is not high. The amount of nitrites is not higher than $0,02 \mathrm{mg} / \mathrm{l}$ in the springs of Utena district, while the limit value is $0,5 \mathrm{mg} / \mathrm{l}$.

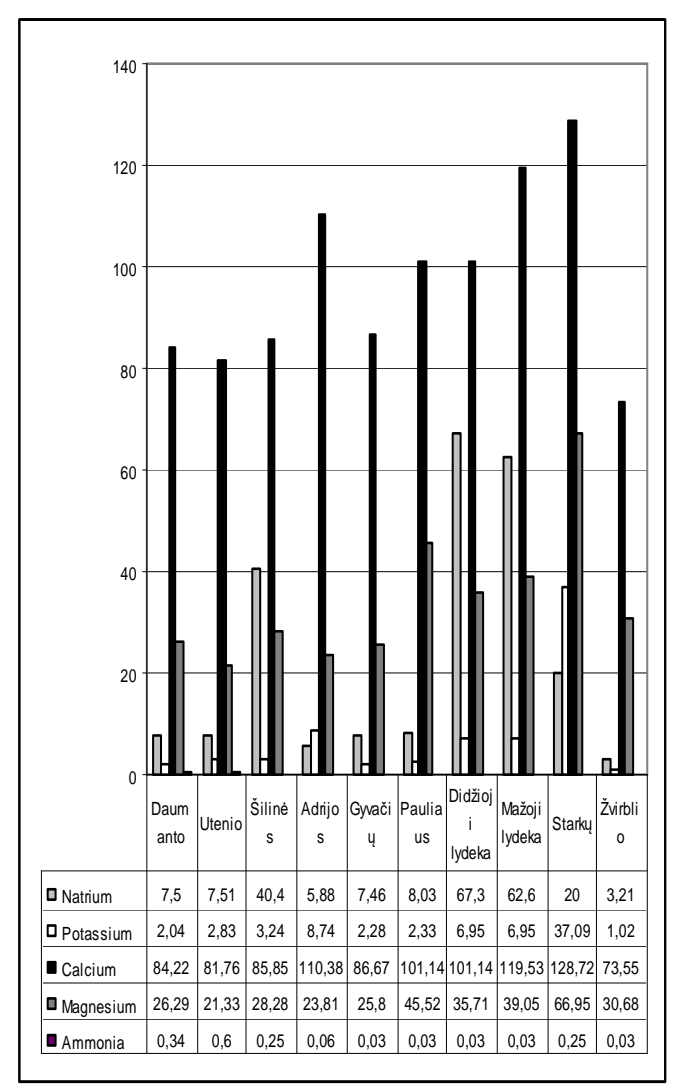

Fig. 6. The amount of cations, mg/l

In the water from Utena district springs calcium, sodium and magnesium cations prevail (Figure 6). HN 24:2003 regulates that two cations have limit values sodium should not exceed $200 \mathrm{mg} / \mathrm{l}$, and ammonium 0,5 $\mathrm{mg} / \mathrm{l}$. The highest level of sodium is in The Great pike's spring $-67,3 \mathrm{mg} / \mathrm{l}$, and the lowest in Zvirblis spring $3,21 \mathrm{mg} / \mathrm{l}$. Ammonium exceed the limit values only in Utenis spring water $(0,6 \mathrm{mg} / \mathrm{l})$.

The water quality in the springs of Utena district is quite good because only ammonium exceed the limit values in one of the springs. The water from Pikes' spring is not recommended to drink but for watering purposes (which is mostly used for now) it is suitable. The water from open springs should be boiled before drinking due to possible microbiological pollution.

\section{CONCLUSIONS}

1. Water springs are significant objects of geo heritage, geo diversity, geo tops, nature, drinking water resources and others.

2. In different springs in Utena district water $\mathrm{pH}$ varies from 7,63 to 8,47 and is slightly alkaline. The distinctive electric conductivity is relatively low from $520 \mu \mathrm{S} / \mathrm{cm}$ to $1081 \mu \mathrm{S} / \mathrm{cm}$. The general hardness of the water is not low, from 5,83 mg-ekv/l to 11,93 mg-ekv/l. The amount of hydro carbonates is from $336,13 \mathrm{mg} / \mathrm{l}$ to $705,27 \mathrm{mg} / \mathrm{l}$. The amounts of chlorides and sulphates are not high. In two water springs the amount of the nitrates is close to $25 \mathrm{mg} / \mathrm{l}$, and in one spring it is $42,28 \mathrm{mg} / \mathrm{l}$. The amount of nitrites is not 
higher than $0,02 \mathrm{mg} / \mathrm{l}$ in the springs of Utena district. The amount of sodium is $3,21-67,3$ $\mathrm{mg} / \mathrm{l}$. Ammonium exceed the limit values only in one water $\operatorname{spring}(0,6 \mathrm{mg} / \mathrm{l})$, so the water quality in Utena district is quite good.

\section{REFERENCES}

[1] The Importance of Geoheritage and Geo Topo f the charts in Inveronmental studies, Environment. Technology. Resources. Proceedings of the 10th International Scientific and practical Conference June 18-20, 2015 Volume II, ISSN 1691-5402, ISBN 978-9984-44-172-6

[2] Geodiversity. [Online]. Available: http://www.onegeology.org/extra/geodiversity/home.html [Accessed: Feb. 22, 2017].

[3] J. Satkūnas, Geoheritage Day. Secrets of Sèliu land geoheritage, (Geologinio paveldo diena. Sèlių žemès geologinio paveldo paslaptys), 2014.
[4] The new objects of geoheritage. [Online]. Available: https://www.lgt.lt/index.php?option=com_content\&view=category \&layout=blog\&id=233\&Itemid=1223\&lang=lt [Accessed: Feb. 15, 2017].

[5] K. Kadūnas at all, Water springs and sources in Lithuania: Aukstadvaris regional park (Lietuvos šaltiniai ir versmès: Aukštadvario regioninis parkas), 2012, pp 5-25

[6] Groundwater. [Online]. Available: https://www.lgt.lt/index.php?option=com_content\&view=article\&i $\mathrm{d}=204 \&$ Itemid=609\&lang=en [Accessed: Feb. 23, 2017]

[7] Springs - The Water Cycle. [Online]. Available: https://water.usgs.gov/edu/watercyclesprings.html

[8] [Accessed: Feb. 22, 2017] 